\title{
NUTRITIONAL STATUS IN RELATION TO THE EFFICACY OF THE RHESUS-HUMAN REASSORTANT, TETRAVALENT ROTAVIRUS VACCINE (RRV-TV) IN INFANTS FROM BELÉM, PARÁ STATE, BRAZIL
}

\author{
Alexandre C. LINHARES(1), Kênea B. do CARMO(1), Krynssya K. OLIVEIRA(1), Consuelo S. OLIVEIRA(1), Ronaldo B. de FREITAS(1), Newton BELLESI(2), \\ Talita A.F. MONTEIRO(1), Yvone B. GABBAY(1) \& Joana D'Arc P. MASCARENHAS(1)
}

\begin{abstract}
SUMMARY
The rhesus-human reassortant, tetravalent rotavirus vaccine (RRV-TV) was licensed for routine use in the United States of America but it was recently withdrawn from the market because of its possible association with intussusception as an adverse event. The protective efficacy of 3 doses of RRV-TV, in its lower-titer $\left(4 \times 10^{4}\right.$ pfu/dose $)$ formulation, was evaluated according to the nutritional status of infants who participated in a phase III trial in Belém, Northern Brazil. A moderate protection conferred by RRVTV was related to weight-for-age Z-scores (WAZ) greater than -1 only, with rates of $38 \%(\mathrm{p}=0.04)$ and $40 \%(\mathrm{p}=0.04)$ for all- andpure rotavirus diarrhoeal cases, respectively. In addition, there was a trend for greater efficacy $(43 \%, p=0.05)$ among infants reaching an height-for-age Z-score (HAZ) of $>-1$. Taking WAZ, HAZ and weight-for-height Z-score (WHZ) indices $\leq-1$ together, there was no significant protection $(\mathrm{p}>0.05)$ if both placebo and vaccine groups are compared. There was no significant difference if rates of mixed and pure rotavirus diarrhoeal cases are compared in relation to HAZ, WAZ and weight-for-height Z-score (WHZ) indices. Although a low number of malnourished infants could be identified in the present study, our data show some evidence that malnutrition may interfere with the efficacy of rotavirus vaccines in developing countries.
\end{abstract}

KEYWORDS: Rotavirus; Vaccine; Nutritional status.

\section{INTRODUCTION}

Worldwide, more than 11 million children in developing countries die annually, during their first year of life; of these deaths, $70 \%$ are due to acute respiratory infections, diarrhoea, measles, malaria, malnutrition or (often) a combination of these conditions ${ }^{9}$. In the global diarrhoeal disease burden scenario, it is estimated that rotaviruses account for 125 million diarrhoeal cases and a minimum of 418,000 to 520,000 deaths per year, $85 \%$ of which in low-income countries ${ }^{10,17}$. There is an additional hazard in these poorer areas of world, since malnutrition makes children more prone to severe disease and, conversely, repeated episodes of diarrhoea may lead to malnutrition ${ }^{1}$. The current concept that rotavirus gastroenteritis will not be controlled by merely improving the water supply, sanitation, or hygiene practices is sustained by the similar incidence of the illness in both industrialized and developing countries ${ }^{2,8}$. During the past two decades, a variety of strategies have been pursued toward the development of an effective rotavirus vaccine, since the "Jennerian approach", using rotavirus strains of animal origin, to the application of molecular biological techniques ${ }^{13}$. In this context, a tetravalent preparation (RRV-TV) combining rhesus-human reassortant strains bearing antigenic specificities for $\mathrm{G}$ serotypes 1,2 and 4 plus the rhesus rotavirus itself as a component having homology with the human $\mathrm{G}$ type 3 has been the most extensively evaluated candidate vaccine to date ${ }^{11,16}$. During the pre-licensing trials, RRV-TV vaccine was administered to over 8,000 children aged 1 to 6 months in both developed and developing countries. Generally, higher efficacy levels were achieved in the former than in the latter regions, and the vaccine appeared to selectively protect against the most severe rotavirus diarrhoeal illness ${ }^{2,13}$. In Belém, Brazil the RRV-TV in its lower titer formulation [4 x $10^{4}$ plaque forming units (pfu)/dose] yielded $35 \%$ and $75 \%$ protective efficacies against all- and- the very severe episodes of rotavirus gastroenteritis, respectively ${ }^{14,15}$.

Although several factors (eg. interference with enterovirus, the challenge of unusual serotypes etc.) have been claimed to explain the usually lower protection achieved by rotavirus vaccines in the lessdeveloped countries, it is likely that malnutrition might play a role $e^{2,13}$. Of interest in this regard, a recent and broadly representative analysis of changes in levels of child malnutrition in the developing world indicated that, despite the overall prevalence of stunting has fallen from $47 \%$ to $33 \%$ during the past 20 years, this condition still remains a major public health problem, mainly in South-central Asia and Eastern Africa ${ }^{6}$.

Currently, no rotavirus vaccine is available for routine use, since RRV-TV ("Rotashield ${ }^{\circledR}$ ") has been withdrawn recently from market because of its association with an increased risk of developing

(1) Seção de Virologia, Instituto Evandro Chagas, Fundação Nacional de Saúde, Ministério da Saúde, Belém, Pará, Brasil

(2) Clínica de Medicina Preventiva do Pará, Belém, Pará, Brasil.

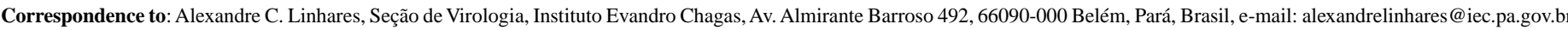




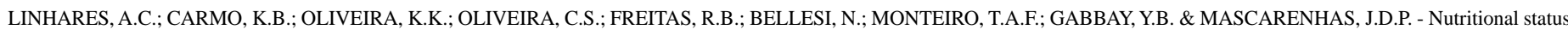
in relation to the efficacy of the rhesus-human reassortant, tetravalent rotavirus vaccine (RRV-TV) in infants from Belém, Pará state, Brazil. Rev. Inst. Med. trop. S. Paulo, 44(1):13-16, 2002 .

intussusception ${ }^{3,4}$. Nevertheless, some of the newer developed candidate vaccines are in late stages of field testing, and lessons learned with RRVTV might be useful when planning future strategies for rotavirus vaccination in the developing countries ${ }^{23}$. In this report we have done an analysis of the RRV-TV efficacy in Belém, Brazil to see whether there was a relationship between the nutritional status and protection conferred by this vaccine.

\section{MATERIALS AND METHODS}

The methodology used to carry out the efficacy trial has been described in details elsewhere ${ }^{14}$. This study was conducted in Belém, Brazil, a city located in the Eastern Amazon with a typical wet tropical climate; half of its estimated population of 1.6 million live under crowded conditions with poor sanitation and all infants enrolled to participate in the trial were from low-income families inhabiting the outskirts of Belém. Briefly, this study was a 2-year, prospective, double-blind, placebocontrolled, randomized trial in which a lower titer $\left[4 \times 10^{4}\right.$ plaque forming unit (pfu)/dose] RRV-TV was evaluated for safety, immunogenicity and efficacy. Altogether, 540 infants received three doses of placebo or RRV$\mathrm{TV}$ at 1,3 and 5 months of age, vaccine protective efficacy being calculated against all rotavirus-positive diarrhoeal episodes and for episodes of pure rotavirus infection, i.e. those in which no other pathogen was identified.

In order to comply with ethical requirements, only healthy, wellnourished infants were recruited to receive the first dose (1 month of age), but indicators of mild/moderate malnutrition that might eventually be detected during the second ( 3 months) and third (5 months) vaccinations were not regarded as exclusion criteria. Just prior to administering each of the three vaccine/placebo doses, relevant data on the past medical history, routine vaccinations and breastfeeding were obtained. In addition, a detailed physical examination was performed by a paediatrician, when both weight and length/height were measured routinely. The EPI INFO software, version 5 [Centers for Disease Control and Prevention, Atlanta, Georgia, United States of America (USA)] was used to calculate the anthropometric indices. Briefly, anthropometric measures (weight and height) were obtained, tabulated and analyzed according to the reference standards of the National Center for Health Statistics and nutritional status was expressed in terms of Z-scores ${ }^{20,21}$. Vaccine efficacy against all- and- pure episodes of rotavirus diarrhoea was evaluated in relation to the means of 3 measurements (first, second and third doses) for height-for-age Z-score (HAZ), weight-for-age Zscore (WAZ), and weight-for-height Z-score (WHZ). These indices were also assessed for all- and- rotavirus-only diarrhoeal episodes. Vaccine efficacy and $95 \%$ confidence intervals were determined as previously described $^{12}$. Differences between both placebo and vaccine groups - as well as between all- and- pure rotavirus gastroenteritis cases - were analyzed using the Mantel-Haenszel $\chi^{2}$ test of association or Fisher's exact test, as appropriate. Significance was defined as $\mathrm{p}<0.05$.

\section{RESULTS}

The protective efficacy of RRV-TV $\left(4 \times 10^{4} \mathrm{pfu} / \mathrm{dose}\right)$ vaccine against all episodes and pure episodes of rotavirus gastroenteritis, according to nutritional status, is summarized in Table 1. Overall, anthropometric indices could be calculated for 79 rotavirus-positive infants allocated either into the placebo $(n=47)$ or vaccine $(n=32)$ groups, of whom 14 $(17.7 \%)$ had HAZ $\leq-2$ when receiving the second $(n=9)$ and the third $(n=5)$ vaccine doses (data not shown in Table). A moderate, but statistically significant, efficacy was achieved among infants with WAZ greater than -1.0 , with protection rates of $38 \%(\mathrm{p}=0.04)$ and $40 \%(\mathrm{p}=$ 0.04 ) against all- and- pure rotavirus diarrhoeal cases, respectively. There was a trend for protection $(43 \%, \mathrm{p}=0.05)$ when HAZ $>-1.0$ was considered for all rotavirus-related diarrhoea cases. The trend was similar $(34 \%, p=0.09)$ for all/pure rotavirus diarrhoea among infants with WHZ scores greater than -1.0 . Taken all anthropometric variables together for both all- and- pure rotavirus gastroenterits cases, no vaccine protection was observed when scores fall below the $>-1.0$ cut-off.

Table 2 shows the anthropometric variables for nutritional status in relation to the occurrence of either pure or mixed rotavirus infection. There was no statistically significant difference $(p>0.05)$ if either $>-1$

\section{Table 1}

Protective efficacy of rhesus-human reassortant, tetravalent rotavirus vaccine $\left(4 \times 10^{4} \mathrm{pfu} / \mathrm{dose}\right)$ against rotavirus gastroenteritis, according to nutritional status of children in Belém, Brazil

\begin{tabular}{|c|c|c|c|c|}
\hline \multirow{2}{*}{$\begin{array}{l}\text { Anthropometric } \\
\text { variables }\end{array}$} & \multicolumn{2}{|c|}{ No. of episodes } & \multirow{2}{*}{$\begin{array}{l}\text { Percentage of } \\
\text { protection } \\
(95 \% \mathrm{CI})\end{array}$} & \multirow[b]{2}{*}{$\mathrm{p}$} \\
\hline & $\begin{array}{c}\text { Placebo } \\
\text { [363] }\end{array}$ & $\begin{array}{c}\text { Vaccine } \\
\text { [361] }\end{array}$ & & \\
\hline \multicolumn{5}{|l|}{ HAZ, all cases } \\
\hline$>-1.0$ & 30 & 17 & $43(0,68)$ & 0.05 \\
\hline-1.0 to -1.99 & 10 & 12 & $-20(-178,47)$ & 0.65 \\
\hline-2.0 to -2.99 & 6 & 2 & $66(-64,6.8)$ & 0.15 \\
\hline$\leq-3.0$ & 1 & 1 & $-1 \quad(-1570,94)$ & 0.75 \\
\hline \multicolumn{5}{|l|}{ HAZ, pure cases } \\
\hline$>-1.0$ & 22 & 13 & $41(-16,70)$ & 0.12 \\
\hline-1.0 to -1.99 & 10 & 10 & $-1 \quad(-138,58)$ & 0.99 \\
\hline-2.0 to -2.99 & 6 & 1 & $83(-39,2.0)$ & 0.06 \\
\hline$\leq-3$ & 1 & 1 & $-1 \quad(-1570,94)$ & 0.75 \\
\hline \multicolumn{5}{|l|}{ WAZ, all cases } \\
\hline$>-1.0$ & 45 & 28 & $38(2,60)$ & 0.04 \\
\hline-1.0 to -1.99 & 1 & 3 & $-200 \quad(-3230,69)$ & 0.31 \\
\hline $\begin{array}{l}-2.0 \text { to }-2.99 \\
\leq-3.0\end{array}$ & 1 & 1 & $-1 \quad(-1570,94)$ & 0.75 \\
\hline \multicolumn{5}{|l|}{ WAZ, pure cases } \\
\hline$>-1.0$ & 37 & 22 & $40(1,64)$ & 0.04 \\
\hline-1.0 to -1.99 & 1 & 2 & $-100(-1900,82)$ & 0.50 \\
\hline-2.0 to -2.99 & 1 & 1 & $-1 \quad(-1570,94)$ & 0.75 \\
\hline$\leq-3.0$ & - & - & -- & - \\
\hline \multicolumn{5}{|l|}{ WHZ, all cases } \\
\hline$>-1.0$ & 38 & 25 & $34(-7,59)$ & 0.09 \\
\hline-1.0 to -1.99 & - & - & -- & - \\
\hline-2.0 to -2.99 & 1 & 0 & $100-$ & 0.50 \\
\hline$\leq-3.0$ & - & - & $-\quad-$ & - \\
\hline \multicolumn{5}{|l|}{ WHZ, pure cases } \\
\hline$>-1.0$ & 38 & 25 & $34(-7,59)$ & 0.09 \\
\hline-1.0 to -1.99 & - & - & $-\quad-$ & - \\
\hline-2.0 to -2.99 & 1 & 0 & $100-$ & 0.50 \\
\hline$\leq-3.0$ & - & - & -- & - \\
\hline
\end{tabular}

[ ], no. of child/years 


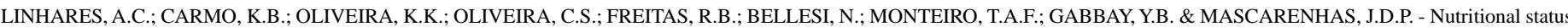
in relation to the efficacy of the rhesus-human reassortant, tetravalent rotavirus vaccine (RRV-TV) in infants from Belém, Pará state, Brazil. Rev. Inst. Med. trop. S. Paulo, 44(1):13-16, 2002 .

Table 2

Nutritional status of children wiht rotavirus-related diarrhoea who participated in a vaccine trial in Belém, Brazil

\begin{tabular}{|c|c|c|c|c|c|c|}
\hline \multirow{2}{*}{$\begin{array}{l}\text { Doses/ } \\
\text { Anthropometric } \\
\text { variables }\end{array}$} & \multicolumn{2}{|c|}{ Vaccine } & \multicolumn{2}{|c|}{ Placebo } & \multicolumn{2}{|c|}{ Total } \\
\hline & Pure* & Mixed** & Pure & Mixed & Pure*** & Mixed $* * *$ \\
\hline \multicolumn{7}{|l|}{$\overline{H A Z}$} \\
\hline$>-1.0$ & 13 & 4 & 22 & 8 & 35 & 12 \\
\hline-1.0 to -1.99 & 10 & 2 & 10 & 0 & 20 & 2 \\
\hline-2.0 to -2.99 & 1 & 1 & 6 & 0 & 7 & 1 \\
\hline$\leq-3.0$ & 1 & 0 & 1 & 0 & 2 & 0 \\
\hline \multicolumn{7}{|l|}{$W A Z$} \\
\hline$>-1.0$ & 22 & 6 & 37 & 8 & 59 & 14 \\
\hline-1.0 to -1.99 & 2 & 1 & 1 & 0 & 3 & 1 \\
\hline-2.0 to -2.99 & 1 & 0 & 1 & 0 & 2 & 0 \\
\hline$\leq-3.0$ & 0 & 0 & 0 & 0 & 0 & 0 \\
\hline \multicolumn{7}{|l|}{$W H Z$} \\
\hline$>-1.0$ & 25 & 7 & 38 & 8 & 63 & 15 \\
\hline-1.0 to -1.99 & 0 & 0 & 0 & 0 & 0 & 0 \\
\hline-2.0 to -2.99 & 0 & 0 & 1 & 0 & 1 & 0 \\
\hline$\leq-3.0$ & 0 & 0 & 0 & 0 & 0 & 0 \\
\hline
\end{tabular}

*, Rotavirus only; **, Rotavirus plus other enteropathogen(s) ***, Pure vs. mixed rotavirus infections for $\boldsymbol{H A Z}, \boldsymbol{W A Z}$ and $\boldsymbol{W H Z}>-1.0$ and $\leq-1.0, \mathrm{p}>0.05$

or $\leq-1$ indices for HAZ, WAZ and WHZ are compared with both pureand- mixed rotavirus infection among infants allocated into either the vaccine or placebo group or both.

\section{DISCUSSION}

The evaluation of the efficacy data from the vaccine trial in Belém, Brazil $^{14}$, according to the nutritional status, suggests that RRV-TV may achieve higher levels of protection among well-nourished than in malnourished infants. This was particularly evident when the means of 3 measurements - taken at first, second and third doses - for WAZ (alland- pure rotavirus diarrhoea) were assessed, but there was a trend for protection among children with both HAZ (all cases) and WHZ (alland-pure diarrhoeal cases) greater than -1.0 . Whatever the anthropometric variable, however, no efficacy could be observed when indices fell below this cut-off point, therefore indicating any degree of malnutrition.

A number of reasons - many of them related to the epidemiology of rotavirus disease - have been postulated to explain the comparatively low vaccine efficacy rates in developing countries, but little emphasis has been placed on the possible role that malnutrition might play in this context $t^{2,13}$. Since the intestinal epithelial surface is known to be altered in association with malnutrition, and, conversely, more receptors are available to rotavirus in well nourished children ${ }^{18}$, it seems likely that the former condition results in a less effective take of the vaccine.

It has been demonstrated that zinc micronutrient plays a central role in the immune system, and that zinc-deficient persons may experience increased susceptibility to a variety of pathogens ${ }^{19}$. Although an immune correlate of protection against rotavirus infection is yet to be established, several studies suggest that local secretory immunoglobulin A ( $\operatorname{Ig} \mathrm{A})$ may play a role in this context $\mathrm{t}^{2,14}$. Since the immunologic mechanisms might be affected by a micronutrient zinc-deficiency condition, it seems likely that rotavirus vaccine take among malnourished infants in Belém, Brazil has been compromised, therefore leading to protective efficacy levels lower than those yielded for well-nourished recipients of RRV-TV. An evidence in support to this hypothesis is that overall protection rate of $35 \%$ seems to be in line with IgA seroconversion rates yielded among vaccinees $(60 \%)$ and placebo-recipients $(30 \%)$, respectively ${ }^{14}$. Since data on the levels of IgA antibodies (seroconversions and geometric mean titres) are only available for a subgroup $(n=160)$ of participating infants, additional analyses may be attempted to associate serum antibody titers with the nutritional status.

Since all rotavirus-positive samples were also processed for both bacterial pathogens and parasites, our study provided the opportunity to assess the nutritional status in relation to pure (rotavirus only) and mixed [rotavirus plus other enteropathogen(s)] infections. There was no significant difference when comparing both pure- and- mixed rotavirus infections with either well-nourished or malnourished infants. This appears to be in contrast with previous findings showing that major bacterial pathogens are more likely to be associated with more severely underweight, wasted and stunted children than those with rotavirus diarrhoea ${ }^{7}$. Conversely, however, studies conducted among Jewish and Bedouin infants in Israel indicate that malnutrition increases considerably the severity of clinical symptoms during natural rotavirus infection, often leading to hospitalization ${ }^{5}$.

There have been some limitations in the present analysis that might have underestimated the impact of malnutrition on the vaccine efficacy. First, a very low number of infants fell under the cut-off point of $\leq-1.0$ for all anthropometric indices, probably as a result of frequent interventions by trained field-workers during our longitudinal, active surveillance rotavirus vaccine trial. Second, in order to comply with protocol/ethical requirementes, only healthy (well-nourished) infants were enrolled to receive the first rotavirus vaccine dose. A more accurate assessment of the impact caused by nutritional status on the rotavirus vaccine efficacy might possibly be achieved in the context of the planned effectiveness, phase IV trials that were planned to be conducted in developing countries ${ }^{22}$.

\section{RESUMO}

\section{Relação entre o estado nutricional e a eficácia da vacina tetravalente contra rotavírus de origem símio-humana, geneticamente rearranjada $(R R V-T V)$, em crianças de Belém, Pará, Brasil}

A vacina tetravalente contra rotavírus de origem símio-humana, geneticamente rearranjada $(R R V-T V)$, foi licenciada para uso rotineiro nos Estados Unidos da América do Norte; entretanto, tal imunizante foi removido do mercado, uma vez que a intussuscepção emergiu como possível evento adverso vacinal. A eficácia da $R R V-T V$ - em sua formulação menos concentrada $\left(10 \times 10^{4} \mathrm{pfu} /\right.$ dose $)$ - foi avaliada no tocante ao estado nutricional das crianças que integraram estudo caracterizado como de fase III, levado a efeito em Belém, região norte do Brasil. Observou-se proteção (moderada) apenas entre os indivíduos 


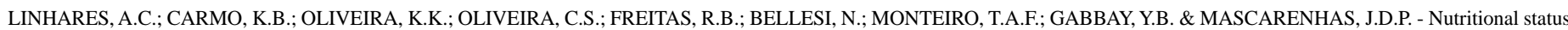
in relation to the efficacy of the rhesus-human reassortant, tetravalent rotavirus vaccine (RRV-TV) in infants from Belém, Pará state, Brazil. Rev. Inst. Med. trop. S. Paulo, 44(1):13-16, 2002 .

com escore " $Z$ " (peso-por-idade, WAZ) superior a -1, com eficácias de $38 \%(\mathrm{p}=0,04)$ e $40 \%(\mathrm{p}=0,04)$ para todos os episódios de diarréia por rotavírus e os caracterizados como "puros" (sem outro enteropatógeno identificado no espécime clínico), respectivamente. A par disso, denotouse tendência a mais elevados níveis protetores $(43 \%, \mathrm{p}=0.05)$ entre crianças que apresentavam escore " $Z$ " (estatura-por-idade, $H A Z)>-1$. Considerando-se conjuntamente os escores " $Z$ " [WAZ, HAZ e peso-porestatura $(W H Z)]$ menores ou iguais a -1 , não se registrou proteção significativa $(\mathrm{p}>0,05)$, uma vez comparadas as crianças que receberam placebo àquelas vacinadas. Também não resultaram expressivas as diferenças, se as infecções "puras" e "mistas" por rotavírus são comparadas relativamente às variáveis antropométricas $H A Z, W A Z$ e WHZ. Não obstante o reduzido número de infantes desnutridos no presente estudo, os resultados disponíveis oferecem evidências de que o estado nutricional pode interferir na eficácia das vacinas contra rotavírus nos países em desenvolvimento.

\section{ACKNOWLEDGMENTS}

The technical assistance provided by Miss Danielle Barros is gratefully acknowledged.

\section{REFERENCES}

1. BERN, C.; MARTINES, J.; de ZOYSA, I. \& GLASS, R.I. - The magnitude of the global problem of diarrhoeal disease: a ten-year update. Bull. Wld. Hlth. Org., 70: 705$714,1992$.

2. BRESEE, J.S.; GLASS, R.I.; IVANOFF, B. \& GENTSCH, J.R. - Current status and future priorities for rotavirus vaccine development, evaluation and implementation in developing countries. Vaccine, 17: 2207-2222, 1999.

3. CDC - Intussusception among recipients of rotavirus vaccine: United States, 1998-1999. M.M.W.R., 48: 577-581, 1999a.

4. CDC - Withdrawal of rotavirus vaccine recommendation. M.M.W.R., 48: 1007, 1999b.

5. DAGAN, R.; BAR-DAVID, Y.; SAROV, B. et al. - Rotavirus diarrhea in Jewish and Bedouin children in the Negev region of Israel: epidemiology, clinical aspects and possible role of malnutrition in severity of illness. Pediat. infect. Dis. J., 9: 314-321, 1990.

6. DE ONIS, M.; FRONGILLO, E.A. \& BLÖSSNER, M. - Is malnutrition declining? An analysis of changes in levels of child malnutrition since 1980. Bull. Wld. Hlth. Org., 78: 1222-1233, 2000.

7. DEWAN, N.; FARUQUE, A.S.G. \& FUCHS, G.J. - Nutritional status and diarrhoeal pathogen in hospitalized children in Bangladesh. Acta Pediat., 87: 627-630, 1998.

8. DE ZOYSA, I. \& FEACHEM, R.G. - Interventions for the control of diarrheal diseases among young children: rotavirus and cholera immunization. Bull. Wld. Hlth. Org., 63: 569-583, 1985.
9. GOVE, S. - Integrated management of childhood illness by outpatient health workers: technical basis and overview. The WHO WORKING GROUP ON GUIDELINES FOR INTEGRATED MANAGEMENT OF THE SICK CHILD. Bull. Wld. Hlth. Org., 75 (suppl 1): S7-S24, 1997.

10. INSTITUTE OF MEDICINE - The prospects for immunizing against rotavirus. In: New vaccine development: establishing priorities. v.2. Diseases of importance in developing countries. Washington, National Academy of Sciences, 1986. p. 308-318.

11. KAPIKIAN, A.Z.; HOSHINO, Y.; CHANOCK, R.M. \& PÉREZ-SCHAEL, I. - Efficacy of quadrivalent rhesus rotavirus-based human rotavirus vaccine aimed at preventing severe rotavirus diarrhea in infants and young children. J. infect. Dis., 174 (suppl. 1): S65-S72, 1996

12. LANATA, C.F. \& BLACK, R.E. - Guideline for design, conduct and analysis of community-based rotavirus vaccine field trials. Lima, Instituto de Investigación Nutricional, 1989. (Scient. Series Publ., n. 1).

13. LINHARES, A.C. \& BRESEE, J.S. - Rotavirus vaccines and vaccination in Latin America. Rev. panamer. Salud públ., 8: 305-331, 2000.

14. LINHARES, A.C.; GABBAY, Y.B.; MASCARENHAS, J.D.P. et al. - Immunogenicity, safety and efficacy of tetravalent rhesus-human, reassortant rotavirus vaccine in Belém, Brazil. Bull. Wld. Hlth. Org., 74: 491-500, 1996.

15. LINHARES, A.C.; LANATA, C.F.; HAUSDORFF, W.P.; GABBAY, Y.B. \& BLACK R.E. - Reappraisal of the Peruvian and Brazilian lower titer tetravalent rhesus-human reassortant rotavirus vaccine efficacy trials: analysis by severity of diarrhea. Pediat. infect. Dis. J., 18: 1001-1006, 1999.

16. MIDTHUN, K.; GREENBERG, H.B.; HOSHINO, Y. et al. - Reassortant rotaviruses as potential live rotavirus candidates. J. Virol., 53: 949-954, 1985.

17. MILLER, M.A. \& McCANN, L. - Policy analysis of the use of hepatitis B, Haemophilus influenzae type B-, Streptococcus pneumoniae-conjugate and rotavirus vaccines, in national immunization schedules. HIth. Econ., 9: 19-35, 2000.

18. RIEPENHOFF-TALTY, M.; LEE, P.C.; CARMODY, R.J.; BARRETT, H.J. \& OGRA, P.L. - Age-dependent rotavirus-enterocytes interactions. Proc. Soc. exp. biol. Med., 170: $146-154,1982$.

19. SHANKAR, A.H. \& PRASAD, A.S. - Zinc and immune function: the biological basis of altered resistance to infection. Amer. J. clin. Nutr., 68 (suppl. 2): S447-S463, 1998.

20. WATERLOW, J.C.; BUZINA, R.; KELLER, W. et al. - The presentation and use of height and weight data for comparing the nutritional status of groups of children under the age of 10 years. Bull. Wld. Hith. Org., 55: 489-498, 1977.

21. WHO WORKING GROUP - Use and interpretation of anthropometric indicators of nutritional status. Bull. Wld. Hlth. Org., 64: 929-941, 1986.

22. WHO - Consensus workshop: rotavirus vaccines for the immunization of children in developing countries. Geneva, WHO/ CDC/ CVI, 1997.

23. WHO - Report of the meeting on future directions for rotavirus vaccine research in developing countries. Geneva, WHO, 2000.

Received: 04 October 2001

Accepted: 10 December 2001 